UDC 378.147.091.39:811.111'276.6:61:[004.9+004.77]

DOI https://doi.org/10.32840/1992-5786.2021.79.1.16

\author{
G. K. Volkova \\ Candidate of Pedagogical Sciences, \\ Associate Professor at the Foreign Languages Department \\ Zaporizhzhia State Medical University
}

G. O. Wieler

Senior Lecturer at the Foreign Languages Department Zaporizhzhia State Medical University

\title{
SMART-TECHNOLOGY IN THE ASYNCHRONIC SYSTEM OF TEACHING ENGLISH TO SMART MEDICAL STUDENTS
}

The article is devoted to the problem of reconsidering approaches to the implementation of existing information technologies, analysis and evaluation of their use in the educational process in order to improve students' cognitive abilities, development of independence, self-affirmation of young people in acquiring and developing professional competencies in the 21st century. The article presents the purpose, objectives and content of Smart education in the Smart-society system, analyzes the features of organization of the educational process using SMART-technologies in foreign language classes in higher medical educational institutions. Nowadays, Smart-learning draws on and highly depends on the use of cloud technologies as well as a wide range of available modern programme applications and other additional options of virtual communication. Such efficient facilities enable young people to get proper education, realize their creative and intellectual potential within the framework of intermediated contact with a teacher and without a fixed place of training.

Witnessing an onward and continual transfer from e-learning to Smart-learning the authors present their own experience in asynchronous learning process, as well as give recommendations for ensuring the practical focus and effectiveness of the educational process, increased motivation and engagement of young people in the learning process, implementation of various forms and types of educational activities in the English language for professional purposes classes with senior medical students. Introduction of innovative approaches, technologies and methods of work with foreign language material while its acquisition as well as developing engagingly original exercises are sure to enhance foreign language skills acquisition in this new paradigm of learning, which will definitely lead to formation of an efficient specialist who complies with the challenges of this new SMART époque. Smart students, in their turn, are sure to get satisfaction with their professional growth as well as comprehension of their readiness to work in the modern world of professional communication.

Key words: SMART-students, SMART-learning, asynchronic teaching, senior medical students, foreign languages acquisition, advanced level, professional competences.

Problem statement. Nowadays the development of mankind is taking place at the background of changes in attitudes to technologies which characterizes a certain level of society development. Educational technologies that serve outdated technological systems and industrial society are based on the so-called academic system of education, meeting the requirements of the labor market, in which knowledge is communicated in the classroom, and the teacher simultaneously performs the functions of communicating knowledge as well as of control and assessment of students' academic achievement. Present day society requires higher education to comply with informatization progress. Educators are facing the task of creative reconsideration of approaches to implementation of existing information technologies, analysis and evaluation of their use in the educational process in order to increase students' cognitive abilities and the formation of independence and self-affirmation of young people in acquiring and developing professional competencies. At present, the traditional academic system of educational services cannot fully meet the requirements of modern students. The answer was the so-called Smart education in the Smart-society system.

Overview of recent research and publications. Active foreign language acquisition is a mandatory factor in the formation of a specialist these days. The works of N.F Borisko, G.A. Kitaygorodskaya, S.Yu. Nikolaeva are devoted to the education of a professional in the process of learning a foreign language. Despite the existing achievements in solving the problem of developing abilities in intercultural communication, the issue of foreign language training of future medical professionals is not fully covered [1, p. 16].

Much research has been done by both domestic and foreign scientists and teachers who have analyzed the pedagogical potential of new information technologies in the educational process. Thus, in particular, the problem of using SMART-technologies in foreign language teaching has been studied by 
B.A. Abdrakhmanova, T.M. Gerasimchuk, I.O. Gogol, G.O. Ivanenko, O.B. Kosovska, O.O. Osova, S.P. Yakubov, J. Park, P. Rizebos and others.

Researchers note that the use of SMARTtechnologies in foreign language classes allows the teacher to achieve positive results: increase the amount of speaking material for both general and professional purposes, which significantly increases the quality and efficiency of the foreign language course; to intensify the cognitive activity of students; to develop creative abilities and logical thinking of students; create conditions for individual research work; realize the possibility of processing a large amount of information. What is more, these researchers note that SMART-technologies provide a practical focus and effectiveness of the learning process; increased motivation of young people to the learning process; contribute to the implementation of various forms and types of educational activities.

We are now witnessing an active transition from e-learning to Smart-learning. The abbreviation "Smart", which was widely used by P. Drucker, while analyzing the structure of management in 1954, includes the following elements: specific, measurable, attainable, relevant, time-bound. However, as noted by L.N. Alekseeva [2], a perfect linguistic translation of this term still does not exist.

The purpose of the article. The abbreviation SMART carries a double meaning: in addition to the literal translation from English, a very interesting interpretation of the name is offered: Self-directed, Motivated, Adaptive, Resource-enriched, Technologyembedded. Today we quite consciously use the terms: Smart-TV, Smart-Home, Smart-Phone. Smart technologies are a way to develop mobility in education, professional employment, social communication.

What is more, many people of all ages work and study remotely, overtime. Such conditions of social interaction will become commonplace. In addition, for the past two years, all higher educational institutions in Ukraine had to work remotely in the pandemic situation. It is worth mentioning that Smarteducation is based on the use of cloud technologies, available types of modern software components and other opportunities for virtual communication. It is these conditions that give young people the opportunity to get a decent education, to realize their creative and intellectual potential within the framework of indirect contact with the teacher, without being tied to the main place of study. Smart learning differs from traditional educational technologies in mobility, globalization, the ability to constantly develop and improve together with external sources. Introduction of Smart-technologies to higher education gives an opportunity to improve the system of distance learning, to organize high-quality and effective creative independent work of young people, to accustom them to persistent development of professionally significant skills and acquisition of appropriate competencies on the basis of general study of important components. The abbreviation SMART carries a double meaning: in addition to the literal translation from English, a very interesting interpretation of the name is offered: Self-directed, Motivated, Adaptive, Resource-enriched, Technology-embedded. Today we quite consciously use the terms: Smart-TV, Smart-Home, Smart-Phone. Smart technologies are a way to develop mobility in education, professional employment, social communication.

From the point of view of typology of methodological classification of educational process academics recognize synchronous and asynchronous training. In synchronous learning, both students and a teacher are in the same place of study at the same time. This type of training is called direct. Participants in the learning process should not be separated by time, but they can be separated by space. This type of training includes classroom sessions and webinars, video conferences, etc., in which there is a direct full or partial connection between the participants of the educational interaction. During asynchronous learning, the teacher and the student are separated by time and distance. The student performs the task in the absence of the teacher on his own schedule outside the classroom in order to demonstrate the performed assignment some time later and then get the teacher's assessment. At the last stage of the assignment preparation, the two opposite sides may not meet at all, however the student receives a grade along with the analysis. As experience shows, a persistent student is not always satisfied with a written feedback. They seek direct communication with the teacher about the nuances of learning.

The purpose of the article is to share the experience of creating Smart teaching materials in English for Smart senior students and using them in the system of asynchronous learning at the Medical University.

We set ourselves the task of considering the meaning and functions of an elective foreign language course in medical schools and substantiating the basic ground of its organization.

Presentation of the main material. English is recognized as an important tool of international communication in academic and professional life, the only way to access knowledge, a condition for effective integration of young people into the world community. Graduates from Ukrainian universities must have such a level of English that will allow them to fully and adequately participate in the educational process and professional life at both national and international levels (they must have at least B2 level of English) [3]. Foreign language education is an important tool that shapes consciousness of an individual and their ability to be socially mobile in the world. It contributes to the dialogue of cultures in a globalized world when dealing with different challenges. 
During the last decade, by order of the Rector of Zaporizhzhia State Medical University, the Department of Foreign Languages conducts special training in English for future scientists, teachers and leading specialists in the field of medicine. The best students of the medical faculties of the university during the last two years of study take an advanced curriculum in English, which is the course called "English for Professional Purposes: Advanced Level". This category of university students is called talented youth, "smarts". It is these young men and women who are the reserve of scientific and pedagogical staff of the Ukrainian higher medical school.

During the two final academic years, students take an Intermediate English course (5th year) and an advanced Medical English course (6th year).

Groups are streamed at every year of studies according to the students' specialization: Medicine and Pediatrics. As a rule, 20-25 students are selected at each year of studies, who make two academic groups. The distribution of students into groups is based on the results of the Placement Test. The course of study comprises a total of 160 hours and is conducted in accordance with the curriculum of the discipline "Foreign language for professional purposes: advanced level". It is created in accordance with the standard of higher education of the second (master's) level of knowledge 22 "Health" specialty 222 "Medicine", 228 "Pediatrics" educational program of master / specialist in medicine [4], which ensures basic requirements of foreign language teaching and organization of the educational process at the final stage in higher medical school.

Foreign language for professional purposes: advanced level as a discipline:

- extends the basics of medical terminology with the aim of providing the students with necessary skills at the license exam "Step 2" and the English language exam as the part of the state qualifying exam, as well as in educational process;

- is based on the study of lexical and grammar material by students in a foreign (English) language and integrates with the disciplines Therapy and Normal and Pathological Anatomy, Normal and Pathological Physiology, Surgery, Traumatology, Obstetrics and Gynecology, Ophthalmology, Otolaryngology, Infectious Diseases, Neuro and Medical Ethics.

Such groups are taught by highly skilled experienced teachers. Training in groups is carried out in accordance with the curriculum custom-designed by teachers for each group, taking into account the students' s level of English. Plans and schedules are annually adjusted and approved at a meeting of the Department of Foreign Languages in September. Classes usually begin in September. The final certification of language knowledge and speaking skills takes place in April.
The course includes practical classes (not less than $50 \%$ of the total number of classes), tutoring classes (not more than $10 \%$ of the total study time), and distance learning, which means students' mastery of the English language material, tailor-made for certain categories of students or the whole group.

Practical offline classes are based on:

- study of the basic professional terminology based on processing original medical texts in a foreign language;

- mastering the skills of reading, comprehension and two-way translation of the text;

- compilation of abstracts and summaries in a foreign (English) language;

- development of communication skills within the subject of the programme.

- During practical distance learning classes with foreign students it is recommended to:

- take notes of lexical and grammar material presented by the teacher;

- perform written assignments;

- make oral presentations on the suggested topic;

- perform a two-way translation;

- participate in discussions, role-play dialogues.

During the 6th year of studies, the final qualification certification comprises 2 stages. Students take tests to determine their level of English for general purposes as well as for professional medical use (English Placement Test) and (Occupational English Language Test for the Health Care Professionals). Speaking skills for professional purposes are assessed by a special commission during the defense of the course work done by students on the basis of original materials (professional articles) in their field of professional interest. Examination board members can objectively assess the students' written and oral language skills by checking their written papers as well as during professional discussions on the problems of modern medicine. The final lesson is held in the form of a conference on medical issues, where future professionals can share in English their professional knowledge obtained at university (based on their overview of medical articles printed in English), demonstrate their ability to respond to professional questions on modern approaches to scientific observations, research of pathological conditions of patients, discuss conditions and means of treatment of diseases, etc.

Based on the test results and the oral interview the assessment board which consists of the leading teachers of English and medical professionals determine each student's level of the English language proficiency and provides the document valid at the university for admission to graduate and postgraduate studies. The foreign language proficiency level is determined according to the global scale, created on the basis of the Common European Framework of Reference for Languages [7, p. 24]. 
The 5th year students undergo an intermediate certification of their speaking skills during an interview on the general English topics.

The elective English course should not only complement the core curriculum, but also improve students' reading, writing, listening and speaking skills within the scope of their medical occupation: case history, patient examination, communication with patients and colleagues on treatment procedures, appointments and recommendations.

During the course medical students realize that English is a key tool for international communication, and a high level of the English language proficiency allows medical professionals to fully and effectively participate in life in their native country and abroad.

Introduction of non-standard approaches, technologies, original tasks, methods of processing a foreign language material, is a favorable factor for the development of students' linguistic competencies. The new learning paradigm encourages modern students to be efficiently independent learners under motivational guidance of their teachers who motivate, organize, coordinate, advise and control the process and results of learning.

The "Professional English Course book" is designed for senior medical students in their $5^{\text {th }}$ and $6^{\text {th }}$ year of studies at a medical university who continue studying English to improve their second language skills or with the purpose of being admitted to graduate and postgraduate studies.

The need to create the Course book is determined by the present day situation, which the world is facing in the time of the COVID-19 pandemics. Future physicians must be aware of the dangers and must be prepared to address the issues of modern medicine together with physicians from other countries. The programme of the course, which is custom designed for the students of the category "Talented Youth" ensures development of professional general and special medical terminology and the development of professional communicative competencies of senior medical students. English language course book for senior students of the $5^{\text {th }}$ and $6^{\text {th }}$ year of studies of the specialty "Medicine" will allow students to develop and improve professional language skills.

The authors of the Course book implemented the latest achievements of domestic and overseas methodological science, took into account the recommendations of experts in preparation for international exams in English while creating the Course book. The purpose of the Course book is to improve receptive and reproductive language skills of students and further form and develop the skills of professional communicative competence. The texts and exercises of the Course book are aimed at expanding the professional potential English grammar and vocabulary of future medical professionals as well as bringing their professional English communication skills to a higher level.

Structurally, the Course book consists of four sections:

- Module 1: Global Diseases.

- Module 2: World Medicine Takes the Challenge of Covid-1.

- Module 3: Systems and Organs of the Human Body Meeting the Challenge of Coronavirus Disease.

- Module 4: Medical English Development under the Influence of New Diseases.

Each of the sections contains such subdivisions: grammar review, vocabulary focus, reading, listening, translation, speaking (interactive communication, individual long turn), and writing.

The sections have almost the same structure: 1) grammar theory and practice. The examples in the textbook are based on general language vocabulary taught in high school and during a Basic English course at university. Necessary explanations with examples are given in tables and models; 2) practical tasks in the form of exercises, tests and quizzes for the formation of grammar skills, containing grammar material given in the theoretical section; 3) lexical material necessary for communication within the framework of the topic specified in the section, which is achieved by performing practical tasks; 4) authentic texts for reading, selected according to the topic of the section, which are available on the Internet (references to sources are provided after each text). The "Reading" section contains a variety of practical tasks created by the authors of the Course book, the purpose of which is to improve skimming and scanning reading skills; 5) audiovisual presentation in the form of several (2-3) short original English-language videos on the topic with authentically created exercises; 6) text materials for summary writing and translation; 7) communicative tasks to improve the skills of professional interactive communication and individual oral presentation in English; 8) practical tasks for the development of skills of professional business written communication, which are provided with theoretical background information on lexical, grammar and structure features of modern writing.

The Course book employs original English language materials that are available on the Internet, to which the authors have created a set of practical tasks.

Students perform the assignments from the Course book independently, outside the classroom, as well as under the teacher's guidance in the classroom. The teacher monitors independent work of students online. The teacher can choose the following types of supervision and control of the students' work: 1) assessing students' work submitted in the form of screenshots or word documents (performing practical tasks of the section: exercises, tests and quizzes); 2) interview on videos, text materials and use of English; 3) conducting computer testing on the topic. 
The final control of receptive and reproductive English language skills (reading, listening, speaking and writing) is carried out during the final lesson offline or at online conferences by performing test tasks with the whole class feedback on the progress.

The duration of the course is determined by the number of sections and makes up 80 hours $(20$ hours per section) within one academic year, but the teacher can extend or reduce the time frame necessary to complete the work on the Course book, taking into account students' performance, language proficiency and study conditions.

Conclusion. The organization of the course "English for Professional Purposes: Advanced Level" at the Medical University shows that nowadays information technology should be considered as a necessary element of the educational process. Textbooks with up-to-date information materials, interactive exercises and communicative tasks based on Smart-technologies and approaches are a powerful learning tool in promotion the development of creative learning activities on both sides of the learning process. In turn, Smart students are getting ready to test their professional and social communication skills, while teachers meet the challenge of creating methodological smart complex in English for teaching smart students.

\section{References:}

1. Іноземна мова за профресійним спрямуванням (Спеціальність «Медицина»).URL: : https:// www.umsa.edu.ua/fakultets/stomat/kafedry/ ukr-znavstva/resources/inozemna-mova-zaprofesiynim-spryamuvannyam-specialnostmedicina (дата звернення 11.07.2021).

2. Алексеева, Л.Н. Инновационные технологии как ресурс эксперимента. Учитель. 2004, № 3. C. 78 .

3. Рашкевич Ю.М. Болонський процес та нова парадигма вищої освіти: монографія. Львів : Вид-во Львівської політехніки, 2014. 168 с.

4. Програма вивчення навчальної дисципліни «Іноземна мова за профресійним спрямуванням, Просунутий рівень» складена відповідно до Стандарту вищої освіти другого (магістерського) рівня галузі знань 22 «Охорона здоров'я» спеціальності 222 «Медицина», 228 «Педіатрія» освітньої програми магістра/ спеціаліста медицини/ авт.-уклад. Г.К. Волкова. Запоріжжя, 2020. 36 с.

5. Загальноєвропейські Рекомендації 3 мовної освіти: вивчення, викладання, оцінювання / Наук. ред. укр. видання С.Ю. Ніколаєва. Перекл. з англ. К.: Ленвіт, 2003. 273 с.

6. Проект Концептуальних засад 3 розвитку електронної освіти в Україні URL: http:// www.mon.gov.ua/pr-viddil/1312/1381224620 (дата звернення 11.07.2021).
7. Абдрахманова Б.А. Смарт-технологии в образовании. URL: www.zkoipk.kz/b2/369-conf.html (дата звернення 11.07.2021).

8. Биков В.Ю. Навчальне середовище сучасних педагогічних систем. Личность в Едином образовательном пространстве : сб. науч. статей I Междунароного образовательного форума (г. Запорожье, 5-7 мая 2010 г.) / под науч. ред. проф. К.Л. Крутий. Часть 2. Запорожье: ООО «ЛИПС» ЛТД, 2010. C. 234-243.

9. Василенко А. Смарт-освіта як чинник інноваційного розвитку суспільства. Smart-ocвima: ресурси та перспективи : матеріали Міжнар. наук.-метод. конф. (Київ, 16-17 жовтня 2014 р.) : тези доповідей. К. : Київ. нац. торг.-екон. ун-т, 2014. C. 25-27.

10.Герасимчук Т.М. Перспективи навчання іноземної мови з метою фрормування професійної компетентності студентів за допомогою інтернет-технологій. Сучасна парадигма викладання іноземних мов у закладах вищої освіти : тези доповідей Міжуніверситетського науковопрактичного семінару. Харків : Національний юридичний університет імені Ярослава Мудрого, 2019. С. 40-44.

11.Гоголь І.О. Модель змішаного навчання іноземної мови студентів немовних вузів. Використання моделі змішаного навчання при викладанні іноземних мов : тези доповідей. Київ : Київ. нац. торг.-екон. ун-т, 2018. С. 23-26.

12.Загальноєвропейські Рекомендації 3 мовної освіти: вивчення, викладання, оцінювання / Наук. ред. укр. видання С.Ю. Ніколаєва. Перекл. з англ. К.: Ленвіт, 2003. 273 с.

13.Іваненко Г.О. Використання інформаційно-комунікативних технологій в навчанні іноземній мові. Smart-освіта: ресурси та перспективи : матеріали Міжнар. наук.-метод. конф. (Київ, 16-17 жовтня 2014 р.) : тези доповідей. К. : Київ. нац. торг.-екон. ун-т, 2014. 350 с. укр., рос. та англ. мовами. С. 61-63.

14. Косовська О.Б. Використання інформативно-комунікативних технологій (інтерактивної дошки) на уроках німецької мови в школі. Сучасні підходи до навчання іноземної мови: шляхи інтеграції школи та ВНЗ : матеріали II Міжнародної конференції. Харків : Харківський національний університет імені В.Н. Каразіна, 2012. С. 60-61.

15.Методика застосування технології SMART Board у навчальному процесі : навчальний посібник / Г.Ф. Бонч-Бруєвич, В.О. Абрамов, Т.І. Косенко. К. : КМПУ імені Б.Д. Грінченка, 2007. $102 \mathrm{c}$.

16.Осова О.О. Досвід використання технологій навчання іноземних мов студентів в умовах смарт-освіти. Педагогіка та психологія. 2018. Вип. 60. С. 53-63. 
17.Пуховська Л.П. Вивчення іноземних мов у контексті формування загальноєвропейського освітнього простору. Сучасні технології викладання іноземних мов у професійній підготовці фахівців : зб. наук. ст. К: КІТЕП, 2000. С. 32-38.

18.Smart-технології в Україні і світі URL: http://molodi.in.ua/smart-tehnolohiji (дата звернення 07.09.2021).

19.Терпиловська В.М. Особливості іншомовної підготовки студентів вищих медичних навчальних закладів. НМУ ім. О.О. Богомольця : наук.-практ. конфо. К., 2012. С. 151-155.

20.Тихомиров В.П. Тихомиров Н.В. Smart-education: новый поход к развитию образования. URL: http://www.elearningpro.ru/forum/topics/ smart-education (дата звернення 02.09.2021).

21.У професію - 3 англійською / Г.К. Волкова. URL: http://zsmu.edu.ua/allnews_uk_170.html (дата звернення 08.08.2021).

22.Якубов С., Якінін Я. Технології SMART та навчальні матеріали. Hi-Tech у школі. 2011. № 3-4. C. 8-11.

23. Jae Hyeong Park, Jeon Won Choi, Young Jun Lee. Analysis of Instruction Models in Smart Education. URL : https://www.google.com/search?q=smart+ in+education \&oq=smart+in+education\&aqs $=$ chrome..69i57j0i512j0i22i30l8.16194j0j15\& sourceid=chrome\&ie=UTF-8; https://files.eric. ed.gov/fulltext/ED562364.pdf (дата звернення 11.07.2021).

24.Shandyrova G.A. Smart Technologies in Education: International and Kazakhstani Experience. URL : https://zkoipk.kz/ru/2016smart1/2696-conf. html (дата звернення 15.07.2021).

25.SMART Sync 2010. Новые функции - SMART Technologies. URL: http://downloads.smarttech. com/media/sitecore/ru/support/product/ smartsync/smartsync2010win/other/newfeaturessync2010win14apr10.pdf (дата звернення 15.08.2021)

26.Palanivel Kuppusamy. Emerging Technologies to Smart Education. URL: https://www.researchgate. net/publication/340261450_Emerging_ Technologies to Smart_Education (дата звернення 20.08.2021).

27.Zhi-Ting Zhu, Ming-Hua Yu. Peter Riezebos. A Research Framework of Smart Education. URL: https://slejournal.springeropen.com/articles/ 10.1186/s40561-016-0026-2 https://rdcu.be/cxDUI (дата звернення 04.09.2021).

\footnotetext{
Волкова Г., Вілер Г. Смарт-технології в асинхронному навчанні англійської мови smart студентів-медиків

Статтю присвячено проблемі переосмислення підходів до реалізації існуючих інформаційних технологій, аналізу і оцінки можливостей їхнього використання в навчальному процесі з метою підвищення когнітивних здібностей студентів, розвитку самостійності, самоствердження молоді під час набуття та розвитку професійних компетентностей. Перед освітянами постає завдання творчого переосмислення підходів до реалізації існуючих інфоормаційних технологій, аналізу й оцінки можливостей їхнього використання в навчальному процесі з метою підвищення когнітивних здібностей студентів та становлення самостійності та самоствердження молоді під час набуття та розвитку профресійних компетентностей.
}

У статmі розкрито мету, завдання та зміст розумної (Smart) освіти у системі Smart-суспільства, проаналізовано особливості організації навчального процесу з використанням SMART-технологій на заняттях з іноземної мови у вищих медичних навчальних закладах. Авторами представлено власний досвід роботи в умовах асинхронного навчання, а також подано рекомендації щодо забезпечення практичної спрямованості та результативності навчального процесу; підвищеної мотивації молодих людей до процесу навчання; втілення різноманітних форм і видів навчальної діяльності на заняттях з англійської мови професійного спрямування зі студентами-медиками старших курсів. Організація курсу «Англійська мова профресійного спрямування: просунутий рівень» у медичному університеті свідчить про те, що інформаційні технології у нашому сьогоденні повинні розглядатися як необхідний елемент навчального процесу. Навчальні посібники, складені на основі сучасних інформаційних матеріалів та укомплектовані інтерактивними вправами i комунікативними завданнями 3 урахуванням Smart-технологій і підходів, є потужним засобом навчання і сприяють розвитку творчої навчальної активності обох сторін навчального процесу. У свою чергу Smart-cmуденти отримують разом із задоволенням від власних досягнень у медичній англійській усвідомлення своєї професійної готовності до випробувань у всесвітньому просторі професійного і соціального спілкування.

Ключові слова: SMART-технології, SMART-студенти медичних вишів, розумна освіта, англійська мова за профресійним спрямуванням, навчальний процес, профресійні компетентності, просунутий рівень. 